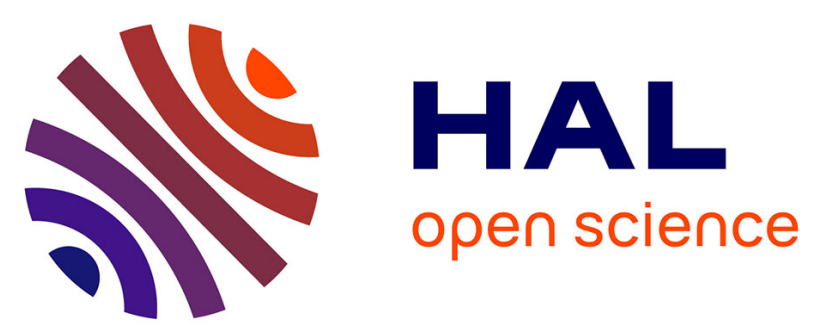

\title{
Resource use of two damselfishes, Stegastes planifrons and Stegastes adustus, on Guadeloupean reefs (Lesser Antilles): Inference from stomach content and stable isotope analysis
}

Charlotte R. Dromard, Yolande Bouchon, Sébastien Cordonnier, Marie-France

Fontaine, Marc Verlaque, Mireille Harmelin-Vivien, Claude Bouchon

\section{To cite this version:}

Charlotte R. Dromard, Yolande Bouchon, Sébastien Cordonnier, Marie-France Fontaine, Marc Verlaque, et al.. Resource use of two damselfishes, Stegastes planifrons and Stegastes adustus, on Guadeloupean reefs (Lesser Antilles): Inference from stomach content and stable isotope analysis. Journal of Experimental Marine Biology and Ecology, 2013, 440, pp.116 - 125. 10.1016/j.jembe.2012.12.011 . hal-01659841

\section{HAL Id: hal-01659841 https://hal.univ-antilles.fr/hal-01659841}

Submitted on 8 Dec 2017

HAL is a multi-disciplinary open access archive for the deposit and dissemination of scientific research documents, whether they are published or not. The documents may come from teaching and research institutions in France or abroad, or from public or private research centers.
L'archive ouverte pluridisciplinaire HAL, est destinée au dépôt et à la diffusion de documents scientifiques de niveau recherche, publiés ou non, émanant des établissements d'enseignement et de recherche français ou étrangers, des laboratoires publics ou privés. 
Resource use of two damselfishes, Stegastes planifrons and Stegastes adustus, on

Guadeloupean reefs (Lesser Antilles): inference from stomach content and stable isotope analysis

Charlotte R. Dromard ${ }^{\mathrm{a},}$, Yolande Bouchon-Navaro ${ }^{\mathrm{a}}$, Sébastien Cordonnier ${ }^{\mathrm{a}}$, Marie-France Fontaine $^{\mathrm{b}}$, Marc Verlaque ${ }^{\mathrm{b}}$, Mireille Harmelin-Vivien ${ }^{\mathrm{b}}$, Claude Bouchon ${ }^{\mathrm{a}}$.

${ }^{a}$ DYNECAR, LABEX CORAIL, Laboratoire de Biologie Marine, Université des Antilles et de la Guyane, 97159 Pointe-à-Pitre, Guadeloupe, France.

${ }^{\mathrm{b}}$ Institut Méditerranéen d'Océanologie (MIO), Aix-Marseille Université, CNRS/IRD UM 110, Campus de Luminy Case 901, 13288 Marseille cedex 9, France.

* Corresponding author: Charlotte Dromard, Laboratoire de Biologie Marine, Université des Antilles et de la Guyane, Campus de Fouillole, B.P. 592, 97159 Pointe-à-Pitre Cedex, Guadeloupe, France.

Email: cdromard@univ-ag.fr

Phone: (590) 590483005

Fax: (590) 590483283 
ABSTRACT Stegastes planifrons and Stegastes adustus are two abundant territorial damselfishes of Caribbean coral reefs. Their trophic niches and their food utilization on Guadeloupean reefs at two contrasting sites were compared on the basis of stomach content and stable isotope analyses $\left({ }^{15} \mathrm{~N} /{ }^{14} \mathrm{~N}\right.$ and ${ }^{13} \mathrm{C} /{ }^{12} \mathrm{C}$ ratios $)$. While ingested food items slightly differed between species, the assimilation of each food source (macroalgae, turf, benthic invertebrates and detritus) calculated with a concentration-dependent mixing model was similar. Macroalgae, that presented the highest nutritional values, contributed to $33 \%$ in biomass of their diet. Invertebrates, algal turf and detritus showed similar nutritional values, while they presented different contributions to the diet of Stegastes. Stable isotope ratios indicated similar fish trophic level and similar isotopic structure on a territory scale, showing a similar trophic niche of the two damselfish at the two sites. However, co-occurrence in the same shallow habitat was associated with a reduction in the size of the territory of $S$. adustus and an increase in the number of species of macroalgae inside their territory, suggesting spatial competitive interactions.

Keywords: coral reefs, stomach content, stable isotope, biochemistry, Pomacentridae, Caribbean. 


\section{Introduction}

In the Caribbean, the degradation of coral communities has been observed over the past few decades, mainly due to the decline of the sea urchin Diadema antillarum Philippi, 1845, coral diseases and overfishing of herbivorous fish, in conjunction with natural and anthropogenic disturbances (global climate change, pollution) (Bouchon et al., 2008a, 2008b; Hughes, 1994). One of the most important consequences of these disturbances is the "algal phase-shift", i.e. the replacement of scleractinian coral dominated communities by macroalgae-dominated communities, which represents a major threat for the balance of coral reef ecosystems (Bruno et al., 2009; Burkepile and Hay, 2006; McManus and Polsenberg, 2004; Norström et al., 2008). However, such disturbances can also have a serious impact on the ecology of coral reef fishes, including habitat changes and the alteration of their ecological and trophic niches (Bozec et al., 2005; Newsome et al., 2007).

On Guadeloupean coral reefs, the threespot damselfish Stegastes planifrons (Cuvier, 1830) and the dusky damselfish Stegastes adustus (Troschel, 1865) are the most abundant territorial damselfish species. Like most of the species of the genus Stegastes Jenyns, 1840, S.

planifrons and S. adustus are referred to as "farmers" and cultivate algal lawns or "turfs" as a food resource in their territory (Ceccarelli et al., 2001). Their aggressive behaviour enables them to exclude larger herbivorous fishes from their territory and to control algal growth (Brawley and Adey, 1977; Ceccarelli et al., 2005; Gobler et al., 2006; Hata and Kato, 2004; Lassuy, 1980; Myrberg and Thresher, 1974; Thresher, 1976). Stegastes play a major role in coral reef ecosystems by their impact on benthic communities. Grazing activities decelerate the succession of algal assemblages, prolonging a high-diversity of algae at a mid-succession stage in algal turf (Ceccarelli, 2007; Ceccarelli et al., 2005; Ferreira et al., 1998; Gobler et al., 2006; Hata et al., 2002; Hinds and Ballantine, 1987; Hoey and Bellwood, 2010; Sammarco, 1983). Moreover, the defence of territories increases the abundance and the species richness 
of benthic invertebrates (Lobel, 1980; Wilson and Bellwood, 1997) and corals (Glynn and Colgan, 1988; Gochfeld, 2009).

While these two species display similar morphology and territorial behaviour, they usually differ in habitat utilization. S. planifrons prefers live corals, especially thickets of Acropora spp (Itzkowitch, 1978; Rivera-Betancourt, 2009; Tolimieri, 1998; Williams, 1978) while $S$. adustus occurs in a less structurally complex and shallower habitat (Emery, 1973; Gutiérrez, 1998; Waldner and Roberston, 1980). However, the recent decline of Acropora species in the Caribbean has forced S. planifrons to move from Acropora to Montastraea species (Precht et al., 2010) in shallower waters. In this study, the two species were spatially separated by depth at the first site, whereas fish territories were found juxtaposed at the same depth at the second site. The close cohabitation of the two species on the reef could involve competitive interactions for place and for food resources.

Several studies have been carried out on S. planifrons and S. adustus, focusing on their territoriality (Mahoney, 1981; Osorio et al., 2006), recruitment (Gutiérrez, 1998), settlement (Precht et al., 2010; Waldner and Robertson, 1980), ecology (Williams, 1978), physiology (Cleveland and Montgomery, 2003) and diet (Emery, 1973; Lobel, 1980; Randall, 1967). However, the comparison of their trophic niches has received little attention, in contrast to damselfishes in other regions (Frédérich et al., 2009; Hata and Umezawa, 2011; Ho et al., 2009).

While behavioural observations in the field provide information on food preferences and feeding patterns, stomach content analysis is the only basis for quantifying fish diet with certainty. However, this necessary method provides a snapshot that reflects the most recent meal, but not the overall diet or the assimilated food (Lajtha and Michener, 1994). Analyses of the ratio of heavy to light isotopes of elements, such as carbon $\left({ }^{13} \mathrm{C} /{ }^{12} \mathrm{C}\right.$ as $\left.\delta^{13} \mathrm{C}\right)$ and nitrogen $\left({ }^{15} \mathrm{~N} /{ }^{14} \mathrm{~N}\right.$ as $\left.\delta^{15} \mathrm{~N}\right)$, represent a useful and complementary tool to study trophic relationships. At the base of the food web, the primary producers often imprint the biological 
molecules that they manufacture with distinct carbon and nitrogen ratios (also called "isotopic signatures"). Consumers incorporate food source signatures in their body, via consumption and tissue synthesis, with a consistent enrichment of stable isotopes at each trophic level (called "fractionation factors"). Thus, stable isotopes can be used to determine the origin of organic matter assimilated by a consumer (Cabana and Rasmussen, 1994; Lajtha and Michener, 1994; Peterson and Fry, 1987; Post, 2002). Isotopic analyses provide information on long-term assimilated food sources and are frequently used to assess the trophic niche widths of species (Bearhop et al., 2004; Newsome et al., 2007). Combining stomach content and isotopic analyses thus represents a powerful approach for diet and trophic niche comparisons.

In addition, the nutritional quality of the food resource may help towards understanding the choice of food made by fishes when feeding (Montgomery and Gerking, 1980). Nutritional quality can be evaluated by measuring the concentrations of proteins, lipids and carbohydrates in food resources. High concentrations of proteins, lipids and soluble carbohydrates represent important reservoirs of energy, and indicate high nutritional quality. In contrast, high concentrations of insoluble carbohydrates (cellulose, lignin) are difficult to digest and indicate low nutritional quality (Choat and Clements, 1998; Krogdahl et al., 2005; Montgomery and Gerking, 1980).

In this study, we compared the trophic niches of S. planifrons and S. adustus at two contrasting sites on Guadeloupean reefs in order to understand how the two species share the resources available. At one site, the two species exhibited depth partitioning with $S$. planifrons living deeper than S. adustus, while at the other site, both species were found in the same shallow habitat. We hypothesised that 1) the two fish species could present similar trophic niches in terms of resources ingestion and assimilation when depth partitioning occurred, 2) the nutritional quality of sources could explain the contributions of food items to fish diet, 3) between site differences in terrigeneous and human influences could induce an 
alteration of the isotopic signatures and 4) alterations of diet and/or behaviour could result from the cohabitation of the two species in the same habitat, revealing competitive interactions.

\section{Material and methods}

\subsection{Study sites}

This study was carried out in Guadeloupe, Lesser Antilles (16 $\left.15^{\prime} \mathrm{N} ; 61^{\circ} 30^{\prime} \mathrm{W}\right)$, on two contrasting reef systems (Fig. 1). One site was located at Ilets Pigeon (IP) on the leeward west coast of the island. From the shore of Ilets Pigeon down to $16 \mathrm{~m}$ depth, the slope is gentle with its higher part composed of rocky blocks colonized by a non reef-building coral community ("veneer reef"). The coral community is dominated by Montastraea annularis (Ellis \& Solander, 1786) and M. faveolata (Ellis \& Solander, 1786) coral species and the coral cover is estimated at around 30\% (Bouchon et al., 2008c). At IP, S. adustus was found from 5 to $8 \mathrm{~m}$ depth on a rocky substratum without coral colonies, while S. planifrons lived deeper, mostly on Montastraea anularis and M. flaveolata colonies, between 12 and $15 \mathrm{~m}$. The other site was located at Passe-à-Colas channel (PC) on the barrier reef of the Grand Cul-de-Sac Marin Bay (GCSM), located on the northern coast of Guadeloupe. This site was located on the top of the steep side of a channel. A calcified flagstone colonized by small coral patches that are better developed on the channel side characterizes this site. At PC, the two damselfish species were found between 10 and $12 \mathrm{~m}$ depth, sharing the same environment. The territories of S. adustus and S. planifrons were similarly constituted of rocks and patches of living coral colonies of Montastraea annularis and Porites porites (Pallas, 1766). Both sites are sheltered from trade-wind surge. The IP site is exposed to moderate currents parallel to the west coast of Guadeloupe. The PC site is a channel cut in the barrier reef where currents alternate in direction according to the tides. During the ebb tide, the site is bathed with lagoonal waters with high sediment and organic matter load, coming from mangrove-bordered coasts. The 
lagoon is also linked to a large river providing waters from surrounding cities. So, Passe-àColas is affected by greater terrigeneous and human influences than Ilets Pigeon.

\subsection{Stomach content analysis}

To study fish diet composition, 5 individuals per species and site were speared between February and April 2010 in the morning (between 09:00 and 11:00 a.m.). As no seasonal difference of diet was observed in these species (Cleveland and Montgomery, 2003; Ferreira et al., 1998), 49 individuals (10 Stegastes planifrons and 15 S. adustus at Ilets Pigeon; 13 S. planifrons and 11 S. adustus at Passe-à-Colas) were speared in July 2010 to increase sample size. Fish were immediately stored in an icebox and transported to the laboratory. Total lengths of fish were measured to the nearest $\mathrm{mm}$. Their size ranged from 96 to $109 \mathrm{~mm}$ for $S$. planifrons and 82 to $120 \mathrm{~mm}$ for $S$. adustus, which corresponded to size at maturity (Froese and Pauly, 2011). Stomachs were removed and preserved in $10 \%$ buffered formalin. Stomach contents were sorted under a binocular microscope into four alimentary categories: algal turf, benthic macroalgae, benthic invertebrates and sediment. Algal turf is defined as upright branches of primarily filamentous taxa and larger algae at a juvenile stage (Hay, 1981), while benthic macroalgae refer to mature erect algae (corticated, fleshy and calcified macroalgae) (Steneck and Dethier, 1994). Due to negligible amounts, sediments were removed from analyses. Each category was oven dried at $50{ }^{\circ} \mathrm{C}$ to constant weight and weighed to the nearest mg after drying. The dry weight of each category was expressed as percentages of the total dry weight of stomach contents for each fish (W\%) (Hyslop, 1980). Benthic invertebrates were identified to phylum and counted before being dried. The mean abundance of each benthic invertebrate phylum in stomach contents was calculated for each species.

Normality and homogeneity of data were tested respectively with Shapiro-Wilks and Levene's tests. Dry weight percentages of each food category were arcsin transformed prior to the analysis and used as response variables. The proportions of each food item were tested with one-way ANOVAs between 4 situations (corresponding to the two fish species at two 
sites). ANOVAs enabled us to perform multiple comparisons with post hoc Tukey's HSD post hoc tests. The number of benthic Invertebrates in stomach contents was compared between fish species with Student $t$ tests.

\subsection{Samplings inside fish territories}

Sampling was performed between February and April 2010. At each site, five territories of each fish species were chosen haphazardly and delimited by a method adapted from Odum and Kuenzler (1955). Aggressive fish movements were observed during 15 minutes. Coloured strips were then placed on the bottom where fish stopped chasing intruders and turned back to mark the boundary of its territory. A picture of each territory was taken to estimate its surface area by a numerical analysis with Adobe ${ }^{\mathrm{TM}}$ Photoshop. As data were normal, territory sizes were compared with one-way analysis of variance (ANOVA), using 4 categories of factor corresponding to the four situations (two sites and two fish species). ANOVAs were combined with a Tukey's honestly significant difference (HSD) post hoc test to perform multiple comparisons.

In each territory, fish were speared, macroalgae hand collected, and turf scraped and collected with an air sucker (Stoddart and Johannes, 1978) connected to a 500- $\mu \mathrm{m}$ meshedcollector bag to sample the benthic invertebrates that were living in the turf. In the laboratory, a small piece of Stegastes dorsal white muscle was sampled and preserved at $-20^{\circ} \mathrm{C}$. Algal turf was sorted under a binocular microscope to exclude all benthic invertebrates, which were preserved independently as a potential food source. Algal turf was not sorted to specific level and was pooled in a single category per territory. Due to the small amount of benthic invertebrates found in turf, they were also pooled in a same category per territory. The different species of macroalgae were sorted and analysed independently. Among the macroalgae species, we recorded the number of species found inside each territory and grouped them into three categories: "palatable", "rare" (species found in only one territory) and "calcified" species. Number of macroalgae species collected inside territories was 
compared with one-way analysis of variance (ANOVA), using 4 categories of factor corresponding to the four situations (two sites and two fish species), followed by Tukey's post hoc test to perform multiple comparisons.

Detritus, including detrital material and bacteria (Crossman et al., 2001), were collected at the bottom of the dishes in which the thalli of macroalgae were cleaned. Detritus were observed with a stereomicroscope to ensure that no epiphytes were collected by this method. All samples were preserved at $-20{ }^{\circ} \mathrm{C}$ before being processed for isotopic or biochemical analyses.

\subsection{Stable isotope analyses and mixing model.}

For stable isotope analyses, the Stegastes white muscle and the potential food sources were freeze-dried before being ground into a homogenous powder. $\mathrm{C}$ and $\mathrm{N}$ stable isotope ratios of fish muscle were determined on the same sample. For food sources, which might contain carbonates (benthic invertebrates, detritus and algal turf), analyses were performed on two subsamples. For $\delta^{13} \mathrm{C}$, a subsample was acidified drop by drop with $1 \mathrm{~N} \mathrm{HCl}$ to remove calcified material that presents a higher $\delta^{13} \mathrm{C}$ than organic material (De Niro and Epstein, 1978). For $\delta^{15} \mathrm{~N}$, a non-acidified subsample was used, as acidification can modify $\delta^{15} \mathrm{~N}$ (Pinnegar and Polunin, 1999). Nitrogen and carbon isotope ratios were determined by a continuous flow mass spectrometer (Thermo FisherTM, delta V Advantage) coupled with an elementary analyzer (Thermo Fisher ${ }^{\mathrm{TM}}$, Flash EA 1112) to measure carbon and nitrogen concentrations $([\mathrm{C}] \%$ and $[\mathrm{N}] \%)$ of the sources. Isotopic ratios were expressed in standard delta notation ( $\delta$ values (\%o)) according to the following formula: $\delta=1000\left[\left(\mathrm{R}_{\text {sample }}-\mathrm{R}_{\text {standard }}\right) /\right.$

$\mathrm{R}_{\text {standard }}-1$ ], where $\mathrm{R}$ is the ratio of the heavy to light isotope (i.e. ${ }^{15} \mathrm{~N}:{ }^{14} \mathrm{~N}$ or $\left.{ }^{13} \mathrm{C}:{ }^{12} \mathrm{C}\right), \mathrm{R}_{\text {sample }}$ is measured for fish and sources and $\mathrm{R}_{\text {standard }}$ is an international standard (Vienna Pee Dee belemnite limestone carbonate for carbon and atmospheric air for nitrogen). 
The Bayesian mixing model SIAR v4.0 (Stable Isotopes Analysis in R) developed by Parnell et al. (2010) was used to estimate the relative contribution of each food source to the diet of the two species. Due to the omnivorous diet of both species (presence of animal and vegetal items) we used the concentration-dependent mixing model as recommended by Phillips and Koch (2002). This model deals with unequal assimilation of carbon and nitrogen, and assumes that for each element, the contribution of a source is proportional to the assimilated biomass times the elemental concentrations in that source. Four mixing models were run with SIAR, corresponding to each fish species at each site. Thus, we entered in each model the respective carbon and nitrogen signatures of fish muscles and sources (mean \pm SD) corresponding to each situation. The model took into account the elemental concentrations $([\mathrm{C}] \%$ and $[\mathrm{N}] \%)$ of source. As isotopic signatures, the mean carbon and nitrogen elemental concentration of sources $( \pm \mathrm{SD})$ were used respectively to the fish territory at each site. The elemental concentrations of macroalgae and algal turf were corrected to consider the indigestible part contained in these two sources. To correct the elemental concentrations of macroalgae and turf, we used the proportions of insoluble carbohydrates measured during the biochemical analysis. The elemental concentrations for invertebrates and detritus were not corrected, because we used the elemental concentrations from acidified samples for these two sources. Without carbonates, invertebrates and detritus are assumed to be entirely digestible (no cellulose or fibers). Finally, the mixing model considers carbon and nitrogen fractionation factors. We calculated $\mathrm{C}$ and $\mathrm{N}$ fractionation factors $\left(\Delta^{13} \mathrm{C}\right.$ and $\left.\Delta^{15} \mathrm{~N}\right)$ according to each situation (two fish territories at each site), using the algorithm described by Caut et al. (2009). Calculations were performed on each food source and the fractionations obtained were then averaged in each situation. We found similar fractionation factors for the four situations, and these values were in agreement with previous studies on Stegastes (Hata and Umezawa, 2011; Mill et al., 2007). Due to their similarity, we used mean $C$ and $N$ fractionation factors $( \pm 95 \%$ 
CI) for the four mixing models: $\Delta^{13} \mathrm{C}=1.6 \pm 0.5 \%$ for carbon and $\Delta \Delta^{15} \mathrm{~N}=5.1 \pm 0.4 \%$ for nitrogen.

Each sample type (muscles, turf, macroalgae, detritus and invertebrates) was compared between sites with non-parametric Kruskal-Wallis one-way analysis of variance because no transformation made data normal and because the size of samples was small. Kruskal-Wallis tests have also been used to compare signatures of each sample type between fish territories at each site. Considering independently the sources collected in S. planifrons and in S. adustus territories at each site, we compared carbon and nitrogen signatures of the potential sources with multivariate analyses of variance (MANOVAs) to ensure that the signatures of sources were statistically different to each other in each situation. Carbon and nitrogen signatures corresponded to the response variables while sample type was used as factor. As differences were demonstrated with MANOVAs, the differences of signatures between the types of source were then tested with one-way ANOVAs in order to perform multiple comparisons with Tukey's HSD post hoc tests.

\subsection{Biochemical analysis}

Concentrations of proteins, lipids, soluble and insoluble carbohydrates were measured in algal turf, detritus, invertebrates and "palatable" macroalgae (ESM 1) associated with Stegastes territories. "Rare" macroalgal species, referring to species found in only one fish territory, were not considered in the biochemical analysis. "Calcified" macroalgal species were also removed from the biochemical analysis because they were not found in stomach contents and they are assumed to be avoided by the fish (Ferreira et al., 1998). Unfortunately, it was not possible to measure biochemical concentrations in benthic invertebrates at Passe-àColas, due to their low abundance. Therefore, the concentrations measured in invertebrates at Ilets Pigeon were used for nutritional analysis for the two sites.

Protein concentrations were measured according to a modified method of Lowry et al. (1951). Soluble and insoluble carbohydrates were determined by a modified method of 
Dubois et al. (1956). Finally, lipids were extracted and measured following the method of Bligh and Dyer (1959), modified by Mayzaud and Martin (1975). All concentrations were expressed as $\mathrm{mg} \mathrm{g}^{-1}$ of matter dry weight.

To compare biochemical concentrations of proteins, lipids and carbohydrates between food categories, we firstly used a MANOVA considering independently the data from each site. When differences were demonstrated with MANOVAs, the differences of concentrations of each macronutrient between food categories were then tested with one-way ANOVAs. Multiple comparisons were then done with Tukey’s HSD post hoc tests. All statistical analyses were performed with $\mathrm{R}$ (version 12.2).

\section{Results}

\subsection{Territory sizes}

Territory sizes showed significant differences according to the four situations (ANOVA, $\left.\mathrm{F}_{(3,38)}=13.6, \mathrm{p}<0.0001\right)$. Results of the Tukey's HSD post-hoc tests are summarized in Table 1. Stegastes adustus defended larger territories at IP than at PC, while S. planifrons defended a similar territory size at the two sites (Table 1). No difference of territory size between species was observed at PC, where the two species coexisted and colonized on average $( \pm$ $95 \% \mathrm{CI}) 1.26( \pm 0.24) \mathrm{m}^{2}$ of reef. However, at IP, where depth partitioning between species was observed, the mean size of territories defended by $S$. adustus was 2.6 times larger than those defended by S. planifrons (Table 1).

\subsection{Composition of macroalgal community within territories}

A total of 25 species of macroalgae were recorded inside fish territories, with higher total species richness at PC than IP (ESM 1). At IP, 6 macroalgal species were collected inside fish territories whereas 24 were found at PC (EMS 1). According to the four situations (two fish territories at two sites), differences have been found in the mean number of "palatable" 
macroalgae per fish territory $\left(\operatorname{ANOVA}, \mathrm{F}_{(3,16)}=11.9, \mathrm{p}=0.0002\right)$ and "calcified" macroalgae per fish territory (ANOVA, $\mathrm{F}_{(3,16)}=19.8, \mathrm{p}=0.0001$ ). At IP, composition and mean number of macroalgal species was similar between territories of the two fish species (Tukey's HSD test, Table 2). At PC, a higher number of palatable and calcified macroalgae species were found inside S. adustus territories than inside S. planifrons territories (Tukey's HSD test, Table 2).

\subsection{Damselfish diet}

According to the four situations (two fish species and two sites), significant differences of ingestion were found for macroalgae (ANOVA, $\left.\mathrm{F}_{(3,44)}=5.9, \mathrm{p}=0.002\right)$, turf (ANOVA, $\mathrm{F}_{(3,44)}$ $=5.3, \mathrm{p}=0.003)$ and invertebrates $\left(\operatorname{ANOVA}, \mathrm{F}_{(3,44)}=16.3, \mathrm{p}=0.0001\right)$.

Stegastes adustus presented a similar diet at both sites with mean proportions $( \pm 95 \% \mathrm{CI})$ of $38.8( \pm 0.2) \%$ of turf, $34.0( \pm 0.9) \%$ of macroalgae and $27.2( \pm 0.7) \%$ of benthic invertebrates (Tukey's HSD tests, all p > 0.99). By the same way, S. planifrons ingested similar proportions of macroalgae and invertebrates at the two sites (Tukey's HSD test, respectively $p=0.06$ and $p=0.94)($ Fig. 2$)$. Concerning the difference of diet between species, S. planifrons ingested a higher proportion of benthic invertebrates than S. adustus at both sites (Tukey's HSD test, $\mathrm{p}=0.0001$, Fig.2).

The same groups of benthic invertebrates were found in the stomach contents of both damselfish species, but in different abundance (Fig. 3). Copepods, gastropods and bivalves were significantly more abundant in $S$. planifrons diet (Student $t$ tests, respectively $t_{27}=14.2$, $\mathrm{p}=0.0001 ; t_{26}=3.19, \mathrm{p}=0.004$ and $\left.t_{27}=2.84, \mathrm{p}=0.008\right)$. No significant difference of polychaete numbers was found between the two species (Student $t$ test, $t_{42}=0.46, \mathrm{p}=0.65$ ), whereas the group "Others" (i.e.: zoea, foraminiferans, ostracods and penaeids) was the only category that was more abundant in $S$. adustus diet (Student $t$ test, $t_{42}=-2.03, \mathrm{p}=0.04$ ). 


\subsection{Stable isotope ratios and trophic structures}

The trophic structure for the two damselfishes at the two sites was illustrated in Fig. 4 by plotting $\delta^{13} \mathrm{C}$ and $\delta^{15} \mathrm{~N}$ values of fish and their four potential food sources: benthic invertebrates, detritus, algal turf and "palatable" macroalgae (Table 3). Calcified and rare species of macroalgae were excluded from the diagram and the models because these species did not represent potential sources for the fish (Montgomery and Gerking, 1980).

Comparisons of isotopic signatures between sites showed a statistically significant enrichment of $\delta^{15} \mathrm{~N}$ of fish muscle, turf, macroalgae and detritus at PC compared to IP (Table 4). No general tendency was found for differences of carbon signatures between sites.

At both sites, Stegastes planifrons muscle presented depleted carbon signatures compared to Stegastes adustus muscle (Table 5). Macroalgae and turf signatures were similar between the two fish territories at each site. Invertebrates and detritus presented variable signatures (Table 5), reflecting the fact that individuals were pooled in the same sample for invertebrates and that detritus corresponded to a mixture of organic matter.

\subsection{Trophic fractionations and source contributions}

Four mixing models were run according to each site and fish species. Sources collected in each case were significantly different from each other (Table 3). In each case, multiple comparisons showed significant difference between signatures of the four types of sources (Tukey's HSD tests, all $\mathrm{p}>0.07$ ). The elemental concentrations of carbon and nitrogen of the sources, used in the mixing model, are shown in Table 3.

Mean trophic-step fractionations for carbon and nitrogen $( \pm \mathrm{SD})$ were used in the four mixing models $\left(\Delta^{15} \mathrm{~N}=5.1 \pm 0.4 \%\right.$ and $\Delta^{13} \mathrm{C}=1.6 \pm 0.5 \%$ ) . The concentration-weighted mixing model indicated similar percentages of contribution of each food item to the diet of the two species (Table 6). Detritus and "palatable" macroalgae, the two most important items in terms of assimilation and mean contribution $( \pm \mathrm{SD})$, were respectively $30.8( \pm 1.1) \%$ and 33.1 
$( \pm 3.3) \%$ of the diet on average (Table 6$)$. Algal turf contributed on average $( \pm$ SD) to $24.2( \pm$ $2.4) \%$ of the diet and benthic invertebrates only $12.0( \pm 3.1) \%$ (Table 6$)$.

\subsection{Biochemical analysis of food resources}

Concentrations of proteins, lipids, and soluble and insoluble carbohydrates differed between food sources at Ilets Pigeon (MANOVA, Wilks' lambda $=0.01, \mathrm{~F}_{(3,37)}=32.5, p=0.0001$ ) and at Passe-à-Colas (MANOVA, Wilks' lambda $=0.08, \mathrm{~F}_{(3,76)}=24.9, p=0.0001$ ). Considered independently, the concentrations of each macronutrient showed significant differences between the food categories (Table 7).

Macroalgae species had the highest concentrations of proteins, carbohydrates and lipids (Tukey's HSD tests, Table 7). No significant differences were found between detritus, turf and invertebrates concentrations, except for higher insoluble carbohydrate concentrations in algal turf (Tukey HSD tests, Table 7).

\section{Discussion}

\subsection{Similar trophic niches for S. planifrons and S. adustus}

Trophic niches of S. adustus and S. planifrons were described by both direct observation of stomach content and by evaluation of the long-term assimilation based on the isotopic approach. The three main food items found in their stomach content (macroalgae, turf and benthic invertebrates) were all benthic sources found inside territories. Emery (1973) in the Florida Keys and Randall (1967) in Puerto Rico also report a high proportion of algal matter in the diet of these fish, linked to their territorial farming activity: $56 \%$ and $79 \%$ for $S$. adustus and $24 \%$ and $77 \%$ for S. planifrons. In the present study, the mean proportion of ingested algal matter (algal turf and macroalgae) reached $48 \%$ in S. planifrons and $73 \%$ in $S$. adustus. Both fish species consumed invertebrates from their territories (polychaetes, molluscs and small crustaceans), with a dominance of copepods for S. planifrons, as already 
observed in the Florida Keys (Emery, 1973). In terms of weight percentage, benthic invertebrates appeared to be the most important item in S. planifrons diet. However, most samples of invertebrates included shells or exoskeletons, which may contribute to an overestimation of their dry weight in stomach contents (Ricciardi and Bourget, 1998). In an additional analysis, we measured the dry weight of shell/exoskeleton-free samples in each category of invertebrates and found that the organic matter represented $46.6 \%$ of the total dry weight for copepods, $42.4 \%$ for gastropods and 39.6\% for bivalves. (C. Dromard, unpublished results). When this weight difference is taken into consideration, benthic invertebrates represented only $9 \%$ and $14.2 \%$ of food ingested by S. planifrons at IP and at PC respectively, and represented $0.2 \%$ and $1.6 \%$ of the food ingested by S. adustus at IP and at PC respectively. Thus, even if the proportion of invertebrates was high in stomach contents, especially for $S$. planifrons, the proportion of organic matter (digestible matter) contained in invertebrates represented a minor part. Detritus was not observed in the stomach content of Guadeloupean damselfish, although it represents a potentially valuable food source for herbivorous fishes (Crossman et al., 2001; Wilson and Bellwood, 1997; Wilson et al., 2003). Its absence could be due to several factors. Firstly, this component is formed by tiny particles rapidly degraded by stomach acids and difficult to identify under the binocular microscope. Secondly, detritus could possibly be related to macroalgae and turf found inside stomach content, but the method used did not allow distinction to be made between them. Detritus was thus considered as a potential food source in the concentration-dependent mixing model, in addition to algal turf, palatable macroalgae and benthic invertebrates. The respective contribution of these four items was similar for both fish species and site. The model highlighted the importance of macroalgae and detritus in the diet of the two Stegastes, with respective mean contributions to fish diet $( \pm \mathrm{SD})$ of $33.1( \pm 3.3) \%$ and $30.8( \pm 1.1) \%$. The importance of macroalgae in Stegastes diet was predictable due to particular farming activities (Ceccarelli et al., 2001). Inside their territory, Stegastes selectively weed out the undesirable 
macroalgae to maximize the abundance of the palatable macroalgae they preferably consume (Hata et al., 2002; Klumpp et al., 1987; Lassuy, 1980). Detritus is a component of relatively unknown composition, origin and dynamics, but of nutritive importance for Stegastes and other herbivorous reef fishes, as evidenced by previous studies (Crossman et al., 2001; Hata and Umezawa, 2011; Wilson and Bellwood, 1997; Wilson et al., 2003). According to the results of mixing models, algal turf represents an intermediate contribution to fish diet, with an average $( \pm$ SD) of $24.2( \pm 2.4) \%$. Stegastes farming activities maintain algal turf growth inside territories by protecting them from browsing by other herbivorous fish in contrast to surrounding substrata (Ceccarelli et al., 2001). While algal turf occupied an important part of the fishes' territory, it contributed moderately to the food assimilated by the damselfish. Finally, previous studies demonstrated that the protection of turf by Stegastes enhances the abundance of small benthic invertebrates (Ferreira et al., 1998; Lobel, 1980; Zeller, 1988). The consumption of invertebrates could supplement fish diet and complement the shortage of nitrogen in vegetal matter (Klumpp et al., 1988; Lobel, 1980; Zeller, 1988), especially for young individuals (Emery, 1973; Lassuy, 1980). In this study, benthic invertebrates represented the lowest assimilated resource in mixing models results, with an average $( \pm$ SD) equal to $12.0( \pm 3.1) \%$. We found a higher contribution of invertebrates in $S$. adustus than in S. planifrons diet, while the ingested proportion measured in stomach contents showed the opposite trend. This fact is probably due to the nature of invertebrates ingested by each species. S. adustus ingested small amounts of invertebrates but most of them were polychaetes, which are easily digestible. In contrast, S. planifrons ingested large amounts of invertebrates and most of them were gastropods, copepods and bivalves, which are difficult to assimilate (shells and exoskeleton). According to stomach content and assimilation analyses, S. planifrons and S. adustus differed slightly in terms of ingestion (with a higher consumption of invertebrates by S. planifrons) and in terms of assimilation (with a higher assimilation of invertebrates by $S$. adustus). However, invertebrates did not represent the principal food 
resource use by the two species and are considered as complements to the diet. Thus, the two fish species presented similar diet and metabolic use of resources, and could be considered as occupying similar trophic niches.

\subsection{Nutritional quality partially explains the assimilation of food items}

The nutritional quality of a resource can be assessed by its biochemical concentrations. High concentrations of proteins, lipids and soluble carbohydrates represent important sources of energy, while a food item with a high proportion of insoluble carbohydrates is less digestible (presence of fibers and cellulose) and represents a resource of low nutritional quality (Cleveland and Montgomery, 2003). Macroalgae, the item most assimilated by Stegastes, were characterized by high nutritional value due to higher concentrations of proteins, soluble carbohydrates and lipids than the three other sources. Turf, invertebrates and detritus showed similar concentrations of proteins, lipids and soluble carbohydrates but each source represented different contributions to the diet of Stegastes. Thus, the nutritional value of food sources partially explains the contribution of sources to the diet of Stegastes. The assimilation of food sources by Stegastes can probably also be linked to their anatomical structure. Algal turf and macroalgae have a similar anatomical structure, but their assimilation by Stegastes differed due to their different nutritional value. Detritus are constituted by small organic particles, easily digestible. With concentrations of proteins, lipids and soluble carbohydrates similar to those of invertebrates and turf, detritus were the second most assimilated sources by Stegastes. In contrast, shells and exoskeletons of invertebrates could reduce their digestibility since Stegastes do not crush their prey, which could explain their low assimilation level.

A more accurate correlation between composition and assimilation of food sources could be measured on the basis of the proportion of inorganic matter in each food source (percentage of ash), i.e. the availability of organic matter in each source. In this study, the low 
assimilation of invertebrates can be linked to the high proportion of inorganic matter measured in invertebrates (C. Dromard, unpublished results). Unfortunately, the proportion of organic/inorganic matter in detritus and turf were not measured in this study. Thus, the assimilation of sources by Stegastes was linked most likely to both their nutritional quality and their anatomical structure.

\subsection{Comparison of trophic structure between fish species and sites}

Usually, the interpretation of stable isotope ratios is based on a constant enrichment from one trophic level to the other, with a mean discrimination factor of $3.4 \%$ for ${ }^{15} \mathrm{~N}\left(\Delta^{15} \mathrm{~N}\right)$ and 1 \%o for ${ }^{13} \mathrm{C}\left(\Delta^{13} \mathrm{C}\right)$ (Minagawa and Wada, 1984; Post, 2002; Vander Zanden and Rasmussen, 2001). However, Mill et al. (2007) explained the higher nitrogen fractionation for herbivorous fishes by differences in diet quality (in term of $\mathrm{C}: \mathrm{N}$ ratio) and metabolism between herbivores and carnivores. The difference of mean isotopic ratios between damselfish and their food sources indicated similar fractionation factors for the two species $\left(\Delta^{15} \mathrm{~N}=5.1 \pm 0.4 \%\right.$ and $\Delta{ }^{13} \mathrm{C}=1.6 \pm 0.5 \%$ ). These factors were in accordance with the values reported for herbivorous fish in previous studies (Barnes et al., 2007; Hata and Umezawa, 2011; Mill et al., 2007; Sweeting et al., 2007). Similar trophic structure was observed for the two Stegastes at the two sites. Macroalgae and turf presented the lower $\delta^{15} \mathrm{~N}$ ratios and were the two main sources of carbon at the base of damselfish food webs. Detritus presented higher $\delta^{15} \mathrm{~N}$ than algal material due to heterogeneous composition and bacterial processes (Chen et al., 2008), while benthic invertebrates were small sized primary consumers with the highest $\delta^{15} \mathrm{~N}$ values of all of the sources. At each site, the two fish species presented high and close $\delta^{15} \mathrm{~N}$ values, indicating a similar trophic level. However S. planifrons showed a slightly depleted $\delta^{13} \mathrm{C}$ muscle signature compared to $S$. adustus, which could be due to differences in fish metabolism previously demonstrated by Cleveland and Montgomery (2003). 
The most conspicuous between-sites difference was an increase in all $\delta^{15} \mathrm{~N}$ values in fish territories at PC compared to IP. One possible explanation of this observation is the physical and chemical differences between sites since a higher human influence was observed at PC than IP. Enriched nitrogen signatures in food webs may indicate anthropogenic disturbances (Lajtha and Michener, 1994; Lepoint et al., 2004). At PC, damselfish territories were located in the channel of the Passe-à-Colas that drains the waters of the Grand Cul-de-Sac Marin (GCSM) contaminated by human activities (Bouchon and Bouchon-Navaro, 1998), which could explain the ${ }^{15} \mathrm{~N}$ enrichment observed there in the Stegastes food web.

\subsection{Habitat alteration involves fish competition for space}

At IP, the two fish species occupied their usual habitats and displayed depth partitioning with S. planifrons occurring deeper than S. adustus. At PC, the two species were found at the same depth, sharing the same environment. Pretch et al. (2010) observed an alteration in the $S$. planifrons microhabitat linked to the degradation of Acropora spp, its preferred habitat. The cohabitation of species with similar ecological niches theoretically results in competitive interaction and exclusion of the lower competitor (e.g. Hutchinson, 1978; Simberloff, 1982). In this study, we compared the trophic niche of the two damselfish species, which represents the bionotic dimension of their ecological niche (resource use) (Newsome et al., 2007). Another dimension is related to habitat and constitutes the scenopoetic dimension of their ecological niche. Although the trophic niches of S. planifrons and S. adustus were similar at both sites, differences in habitat characteristics were observed at PC. At this site, the two species were located at the same depth and $S$. adustus presented a smaller territory size than at IP, where the two species were spatially separated. This decrease in territory size could indicate competition for space between the two species and a lower competitive status in $S$. adustus. A higher number of calcified macroalgae were also observed in S. adustus territory at PC, while undesirable algae are generally selectively weeded out of territories by the fish 
(Hata et al., 2002; Klumpp et al., 1987; Lassuy, 1980). The presence of these unpalatable macroalgae could be due to a decrease in the time dedicated to algae sorting and an increase in time devoted to chasing the new neighbouring species.

Climate change and disturbances of coral reef ecosystems involve important alterations of habitat and consequently of ecological niches of fish. A temporal survey in sites where the two species co-occur, including the study of physical and chemical characteristics of surrounding waters, would provide a basis for determining whether these damselfish could coexist in the long term, through their exclusive use of their own territorial food resources, or whether the ecological imbalance produced by disturbance would induce the spatial exclusion of the least competitive species.

\section{Acknowledgements}

The authors express their thanks to the National Park of Guadeloupe for their authorization to conduct this research in the marine park. Many thanks are expressed to Dr. Pierre Richard and Gaël Guillou, Université de la Rochelle- CNRS UMR LIENSs, for performing stable isotope analyses, and to Michael Paul, a native English-speaker, for correction of the English. We also thank the two referees for their constructive comments on an earlier draft of the manuscript.

\section{References}

Barnes, C., Sweeting, C.J., Jennings, S., Barry, J., Polunin, N.V.C., 2007. Effect of temperature and ration size on carbon and nitrogen stable isotope trophic fractionation. Funct. Ecol. 21, 356-362. 
Bearhop, S., Adams, C.E., Waldron, S., Fuller, R.A., Macleod, H., 2004. Determining trophic niche width: a novel approach using stable isotope analysis. J. Anim. Ecol. 73, 10071012

Bligh, E., Dyer, W., 1959. A rapid method of total lipid extraction and purification. Can. J. Physiol. Pharmacol. 37, 911-917.

Bouchon, C., Bouchon-Navaro, Y., 1998. La Guadeloupe, in: Gabrié, C. (Eds.), L'état des récifs coralliens en France Outre mer. Ministère de l'aménagement du territoire et de l'environnement, Paris, pp. 107-117.

Bouchon, C., Portillo, P., Bouchon-Navaro, Y., Louis, M., Hoetjes, P., Brathwaite, A., Roach, R., Oxenford, H., O’Farrell, S., Day, O., 2008a. Status of the coral reefs of the Lesser Antilles after 2005 coral bleaching event, in: Wilkinson, C. et al. (Eds.), Status of Caribbean coral reefs after bleaching and hurricanes in 2005. Global Coral Reef Monitoring Network and Reef and Rainforest Research Center, Townsville, pp. 85104.

Bouchon, C., Portillo, P., Bouchon-Navaro, Y., Louis, M., Hoetjes, P., De Meyer, K., Armstrong, H., Datadin, V., Hardings, S., Mallela, J., Parkinson, R., Van Bochove, J.W., Wynne, S., Macrae, D., Lirman, D., Herlan, J., Baker, A., Collado, L., Nimrod, S., Mitchell, J., Morrall, C., Isaac, C., 2008b. Status of the coral reefs of the Lesser Antilles in 2008: the French West Indies, the Netherlands Antilles, Anguilla, Antigua and Barbuda, Grenada, Trinidad and Tobago, in: Wilkinson, C. et al. (Eds.), Status of the coral reefs of the world Vol. 3. Australian Institute of Marine Sciences, Australia, pp. $265-280$.

Bouchon, C., Portillo, P., Louis, M., Mazeas, F., Bouchon-Navaro, Y., 2008c. Evolution récente des récifs coralliens des îles de la Guadeloupe et de Saint-Barthelemy. Rev. Ecol. 63, 45-65. 
Bozec, Y.M., Kulbicki, M., Chassot, E., Gascuel, D., 2005. Trophic signature of coral reef fish assemblages: towards a potential indicator of ecosystem disturbance. Aquat. Living Resour. 18, 103-109.

Brawley, S.H., Adey, W.H., 1977. Territorial behavior of threespot damselfish (Eupomacentrus planifrons) increases reef algal biomass and productivity. Environ. Biol. Fishes. 2, 45-51.

Bruno, J.F., Sweatman, H., Precht, W.F., Selig, E.R., Schutte, V.G.W., 2009. Assessing evidence of phase shifts from coral to macroalgal dominance on coral reefs. Ecology. $90,1478-1484$.

Burkepile, D.E., Hay, M.E., 2006. Herbivore vs. nutrient control of marine primary producers: context-dependent effects. Ecology. 87, 3128-3139.

Cabana, G., Rasmussen, J.B., 1994. Modelling food chain structure and contaminant bioaccumulation using stable nitrogen isotopes. Nature. 372, 255-257.

Caut, S., Angulo, E., Courchamp, F., 2009. Variation in discrimination factors $\left(\Delta^{15} \mathrm{~N}\right.$ and $\Delta^{13} \mathrm{C}$ ): the effect of diet isotopic values and applications for diet reconstruction. J. Appl. Ecol. 46, 443-453.

Ceccarelli, D.M., Jones, G.P., McCook, L.J., 2001. Territorial damselfishes as determinants of the structure of benthic communities on coral reefs. Oceanog. Mar. Biol. Annu. Rev. $39,355-389$.

Ceccarelli, D.M., Jones, G.P., McCook, L.J., 2005. Effects of territorial damselfish on an algal-dominated coastal coral reef. Coral Reefs. 24, 606-620.

Ceccarelli, D.M., 2007. Modification of benthic communities by territorial damselfish: a multi-species comparison. Coral Reefs. 26, 853-866.

Chen, F.R., Zhang, L., Yang, Y.Q., Zhang, D.R., 2008. Chemical and isotopic alteration of organic matter during early diagenesis: Evidence from the coastal area off-shore the Pearl River estuary, south China. J. Marine Syst. 74, 372-380. 
Choat, J.H., Clements, K.D., 1998. Vertebrate herbivorous in marine and terrestrial environments: a nutritional ecology perspective. Annu. Rev. Ecol. Syst. 29, 375-403.

Cleveland, A., Montgomery, W.L., 2003. Gut characteristics and assimilation efficiencies in two species of herbivorous damselfish (Pomacentridae: Stegastes dorsopunicans and S. planifrons). Mar. Biol. 142, 35-44.

Crossman, D.J., Choat, J.H., Clements, K.D., Hardy, T., McConochie, J., 2001. Detritus as food for grazing fishes on coral reefs. Limnol. Oceanogr. 46, 1596-1605.

De Niro, M.J., Epstein, S., 1978. Influence of diet on the distribution of carbon isotopes in animals. Geochim. Cosmochim. Acta. 42, 495-506.

Dubois, M., Gilles, K., Hamilton, J., Rebers, P., Smith, F., 1956. Colorimetric method for determination of sugars and related substances. Anal. Chem. 28, 350-356.

Emery, A.R., 1973. Comparative ecology and functional osteology of fourteen species of damselfish (Pisces: Pomacentridae) at Alligator Reef, Florida Keys. Bull. Mar. Sci. 23, $649-770$.

Ferreira, C.E.L., Gonçalves, J.E.A., Coutinho, R., Peret, A.C., 1998. Herbivory by the dusky damselfish Stegastes fuscus (Cuvier, 1830) in a tropical rocky shore: effects on the benthic community. J. Exp. Mar. Biol. Ecol. 229, 241-264.

Frédérich, B., Fabri, G., Lepoint, G., Vandewalle, P., Parmentier, E., 2009. Trophic niches of thirteen damselfishes (Pomacentridae) at the Grand Récif of Toliara, Madagascar. Ichthyol. Res. 56, 10-17.

Froese, R., Pauly, D., 2011. Fishbase. World wide web electronic publication. http://www.fishbase.org (last access: august 2012).

Glynn, P., Colgan, M., 1988. Defense of corals and enhancement of coral diversity by territorial damselfishes. Proc. 6th Int. Coral. Reef Symp. 2, 157-163.

Gobler, C.J., Thibault, D.B., Davis, T.W., Curran, P.B., Peterson, B.J., Liddle, L.B., 2006. Algal assemblages associated with Stegastes sp. territories on Indo-Pacific coral reefs: 
Characterization of diversity and controls on growth. J. Exp. Mar. Biol. Ecol. 336, $135-145$.

Gochfeld, D.J., 2009. Territorial damselfishes facilitate survival of corals by providing an associational defence against predators. Mar. Ecol. Prog. Ser. 398, 137-148.

Gutiérrez, L., 1998. Habitat selection by recruits establishes local patterns of adult distribution in two species of damselfishes: Stegastes dorsopunicans and S. planifrons. Oecologia. $115,268-277$.

Hata, H., Nishihira, M., Kamura, S., 2002. Effects of habitat-conditioning by the damselfish Stegastes nigricans (Lacepède) on the community structure of benthic algae. J. Exp. Mar. Biol. Ecol. 280, 95-116.

Hata, H., Kato, M., 2004. Monoculture and mixed-species algal farms on a coral reef are maintained through intensive and extensive management by damselfishes. J. Exp. Mar. Biol. Ecol. 313, 285-296.

Hata, H., Umezawa, Y., 2011. Food habits of the farmer damselfish Stegastes nigricans inferred by stomach content, stable isotope, and fatty acid composition analyses. Ecol. Res. 26, 809-818.

Hay, M.E., 1981. The functional morphology of turf-forming seaweeds: persistence in stressful marine habitats. Ecology. 62, 739-750.

Hinds, P.A., Ballantine, D.L., 1987. Effects of the Caribbean threespot damselfish, Stegastes planifrons (Cuvier), on algal lawn composition. Aquat. Bot. 27, 299-308.

Ho, C., Fu, Y.C., Sun, C.L., Kao, S.J., Jan, R.Q., 2009. Plasticity of feeding habits of two Plectroglyphidodon damselfishes on coral reefs in southern Taiwan: evidence from stomach content and stable isotope analyses. Zool. Stud. 48, 649-656.

Hoey, A.S., Bellwood, D.R., 2010. Damselfish territories as a refuge for macroalgae on coral reefs. Coral Reefs. 29, 107-118. 
Hughes, T.P., 1994. Catastrophes, phase shifts, and large-scale degradation of a Caribbean coral reef. Science. 265, 1547-1551.

Hutchinson, G.E., 1978. An introduction to population biology. Yale University Press, New Haven.

Hyslop, E.J., 1980. Stomach contents analysis. A review of methods and their application. J. Fish Biol. 17, 411-429.

Itzkowitch, M., 1978. Group organization of a territorial damselfish, Eupomacentrus planifrons. Behaviour. 65, 125-137.

Klumpp, D.W., McKinnon, D., Daniel, P., 1987. Damselfish territories: Zones of high productivity on coral reefs. Mar. Ecol. Prog. Ser. 40, 41-51.

Klumpp, D.W., McKinnon, A.D., Mundy, C.N., 1988. Motile cryptofauna of a coral reef: abundance, distribution and trophic potential. Mar. Ecol. Prog. Ser. 45, 95-108.

Krogdahl, A., Hemre, G.I., Mommsen, T.P., 2005. Carbohydrates in fish nutrition: digestion and absorption in postlarval stages. Aquac. Nutr. 11, 103-122.

Lajtha, K., Michener, R.H., 1994. Stable isotopes in ecology and environmental science. Wikey-Blackwell, Oxford.

Lassuy, D.R., 1980. Effects of farming behavior by Eupomacentrus lividus and Hemiglyphidodon plagiometopon on algal community structure. Bull. Mar. Sci. 30, 304-312.

Lepoint, G., Dauby, P., Gobert, S., 2004. Applications of C and N stable isotopes to ecological and environmental studies in seagrass ecosystems. Mar. Pollut. Bull. 49, 887-891.

Lobel, P.S., 1980. Herbivory by damselfishes and their role in coral reef community ecology. Bull. Mar. Sci. 30, 273-289.

Lowry, O.H., Rosebrough, N.J., Farr, A.L., Randall, R.J., 1951. Protein measurement with the Folin phenol reagent. J. Biol. Chem. 193, 265-275. 
Mahoney, B.M., 1981. An examination of interspecific territoriality in the dusky damselfish, Eupomacentrus dorsopunicans Poey. Bull. Mar. Sci. 31, 141-146.

Mayzaud, P., Martin, J.L.M., 1975. Some aspect of the biochemical and mineral composition of marine plankton. J. Exp. Mar. Biol. Ecol. 17, 297-310.

McManus, J.W., Polsenberg, J.F., 2004. Coral-algal phase shifts on coral reefs: ecological and environmental aspects. Prog. Oceanogr. 60, 263-279.

Mill, A.C., Pinnegar, J.K., Polunin, N.V.C., 2007. Explaining isotope trophic step fractionation: why herbivorous fish are different. Funct. Ecol. 21, 1137-1145.

Minagawa, M., Wada, E., 1984. Stepwise enrichment of $15 \mathrm{~N}$ along food chains: further evidence and the relation between $\delta^{15} \mathrm{~N}$ and animal age. Geochim. Cosmochim. Acta. $48,1135-1140$.

Montgomery, W.L., Gerking, S.D., 1980. Marine macroalgae as food for fishes: an evaluation of potential food quality. Env. Biol. Fish. 5, 143-153.

Myrberg, A.A., Thresher, R.E., 1974. Interspecific aggression and its relevance to the concept of territoriality in reef fishes. Am. Zool. 14, 81-96.

Newsome, S.D., Martinez del Rio, C., Bearhop, S., Phillips, D.L., 2007. A niche for isotopic ecology. Front. Ecol. Environ. 5, 429-436.

Norström, A.V., Nyström, M., Lokrantz, J., Folke, C., 2008. Alternative states on coral reefs: beyond coral-macroalgal phase shifts. Mar. Ecol. Prog. Ser. 376, 295-306.

Odum, E.P., Kuenzler, E.J., 1955. Measurement of territory and home range size in birds. Auk. 72, 128-137.

Osorio, R., Rosa, I., Cabral, H., 2006. Territorial defence by the Brazilian damsel Stegastes fuscus (Teleostei: Pomacentridae). J. Fish Biol. 69, 233-242.

Parnell, A.C., Inger, R., Bearhop, S., Jackson, A.L., 2010. Source partitioning using stable isotopes: coping with too much variation. PloS ONE. 5:e9672. 
Peterson, B.J., Fry, B., 1987. Stable isotopes in ecosystem studies. Annu. Rev. Ecol. Syst. 18, 293-320.

Phillips, D.L., Koch, P.L., 2002. Incorporating concentration dependence in stable isotope mixing models. Oecologia. 130, 114-125.

Pinnegar, J.K., Polunin, N.V.C., 1999. Differential fractionation of $\delta^{13} \mathrm{C}$ and $\delta^{15} \mathrm{~N}$ among fish tissues: implication for the study of trophic interactions. Funct. Ecol. 13, 225-231.

Post, D.M., 2002. Using stable isotopes to estimate trophic position: models, methods, and assumptions. Ecology. 83, 703-718.

Precht, W.F., Aronson, R.B., Moody, R.M., 2010. Changing patterns of microhabitat utilization by the threespot damselfish, Stegastes planifrons, on Caribbean reefs. PloS ONE. 5:e10835.

Randall, J.E., 1967. Food habits of reef fishes of the West Indies. Stud. Trop. Oceanogr. 5, $665-847$.

Ricciardi, A., Bourget, E., 1998. Weight-to-weight conversion factors for marine benthic macroInvertebrates. Mar. Ecol. Prog. Ser. 163, 245-251.

Rivera-Betancourt, G.A., 2009. Population dynamics and resource utilization by the dusky damselfish, Stegastes adustus (Troschel, 1865). PhD thesis, University of Puerto Rico, Puerto Rico.

Sammarco, P.W., 1983. Effects of fish grazing and damselfish territoriality on coral reef algae. I. Algal community structure. Mar. Ecol. Prog. Ser. 13, 1-14.

Simberloff, D.S., 1982. The status of competition theory in ecology. Ann. Zool. Fennici. 19, 241-253.

Steneck, R.S., Dethier, M.N., 1994. A functional group approach to the structure of algaldominated communities. Oikos. 69, 476-498.

Stoddart, D.R., Johannes, R.E., 1978. Coral reefs: research methods. UNESCO, Paris. 
Sweeting, C.J., Barry, J., Polunin, N.V.C., Jennings, S., 2007. Effects of body size and environment on diet-tissue $\delta^{13} \mathrm{C}$ fractionation in fishes. J. Exp. Mar. Biol. Ecol. 352, 165-176.

Thresher, R.E., 1976. Field experiments on species recognition by the threespot damselfish, Eupomacentrus planifrons, (Pisces: Pomacentridae). Anim. Behav. 24, 562-569.

Tolimieri, N., 1998. Contrasting effects of microhabitat use on large-scale adult abundance in two families of Caribbean reef fishes. Mar. Ecol. Prog. Ser. 167, 227-239.

Vander Zanden, M.J., Rasmussen, J.B., 2001. Variation in $\delta^{15} \mathrm{~N}$ and $\delta^{13} \mathrm{C}$ trophic fractionation: implications for aquatic food web studies. Limnol. Oceanogr. 46, 20612066.

Waldner, R.E., Robertson, D.R., 1980. Patterns of habitat partitioning by eight species of territorial Caribbean damselfishes (Pisces: Pomacentridae). Bull. Mar. Sci. 30, 171186.

Williams, A.H., 1978. Ecology of threespot damselfish: social organization, age structure, and population stability. J. Exp. Mar. Biol. Ecol. 34, 197-213.

Wilson, S.K., Bellwood, D.R., 1997. Cryptic dietary components of territorial damselfishes (Pomacentridae, Labroidei). Mar. Ecol. Prog. Ser. 153, 299-310.

Wilson, S.K., Bellwood, D.R., Choat, J.H., Furnas, M.J., 2003. Detritus in the epilithic algal matrix and its use by coral reef fishes. Oceanogr. Mar. Biol. Annu. Rev. 41, 279-309.

Zeller, D.C., 1988. Short-term effects of territoriality of a tropical damselfish and experimental exclusion of large fishes on Invertebrates in algal turfs. Mar. Ecol. Prog. Ser. 44, 85-93. 
Figure

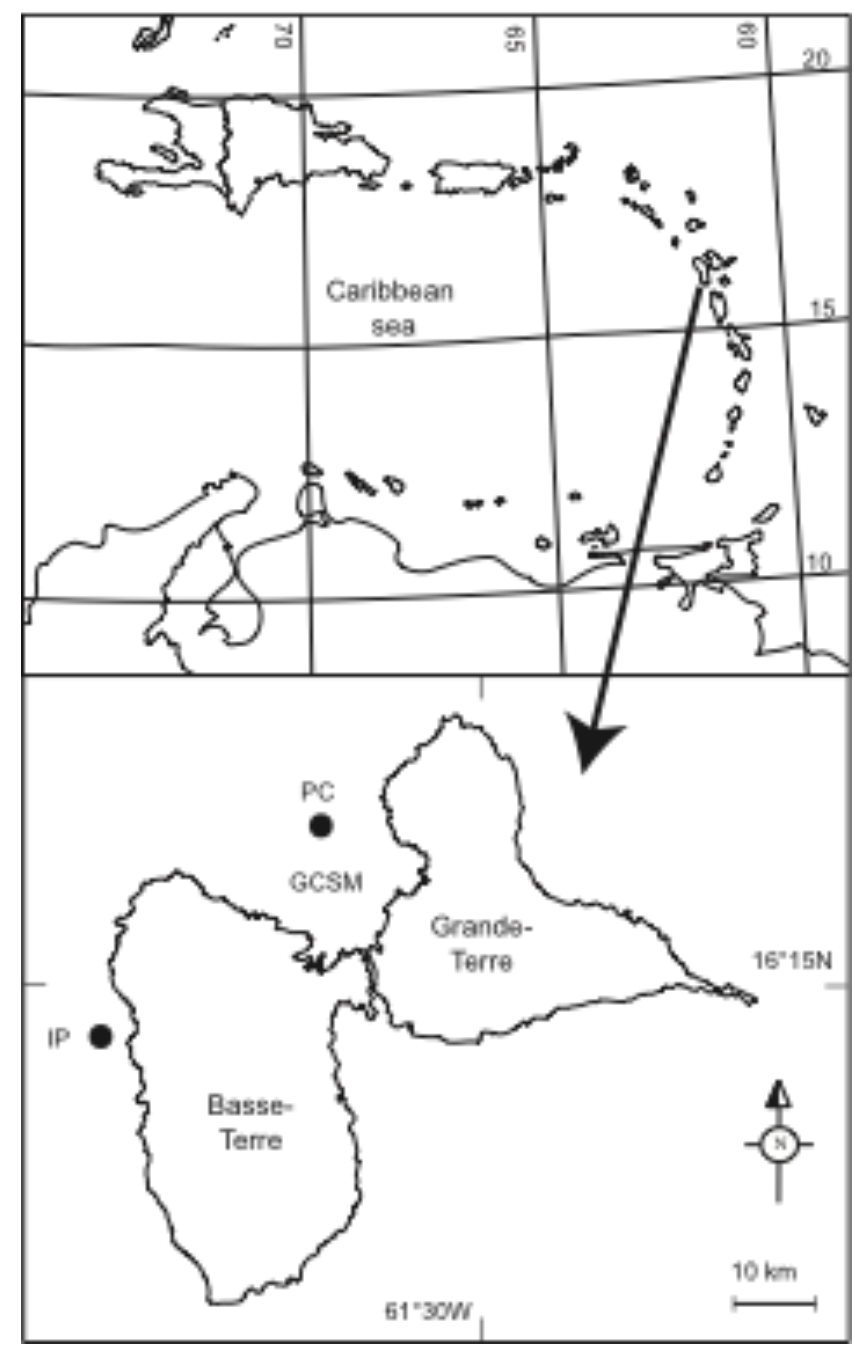

Fig. 1 Location of Guadeloupe in the Caribbean (A) and locations of the two sites studied at Guadeloupe (B). IP: Ilets Pigeon; PC: Passe-à-Colas; GCSM: Grand-Cul-de-Sac-Marin bay 

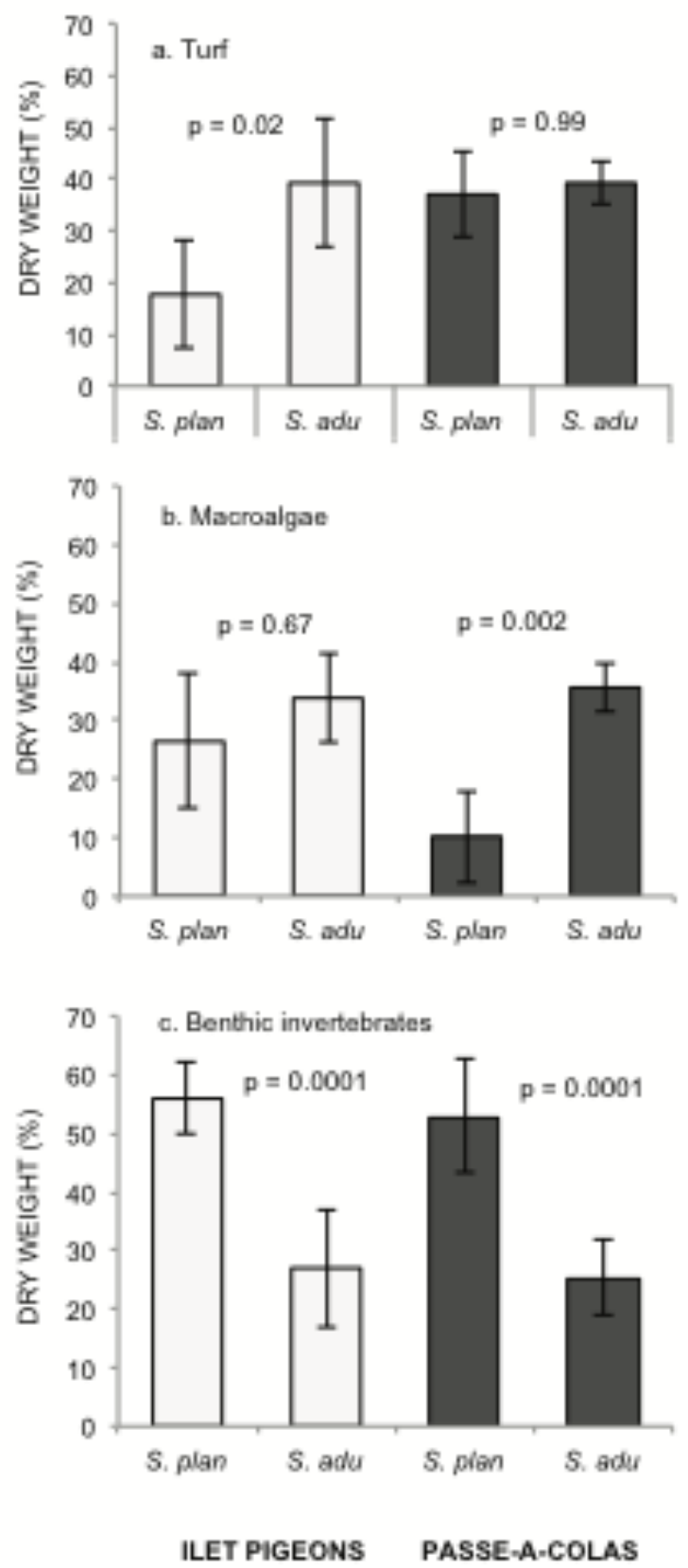

Fig. 2 Dry weight percentages $(\% \pm 95 \% \mathrm{CI})$ of algal turf (a), macroalgae (b) and benthic invertebrates (c) in the diet of Stegastes planifrons (S. plan) and Stegastes adustus $(S . a d u)$ at Ilets Pigeon and Passe-à-Colas. The ingested proportions of each food items were compared with Tukey's HSD post hoc tests between four situations (two fish species and two each site). Data were arcsin transformed prior to the analysis. 

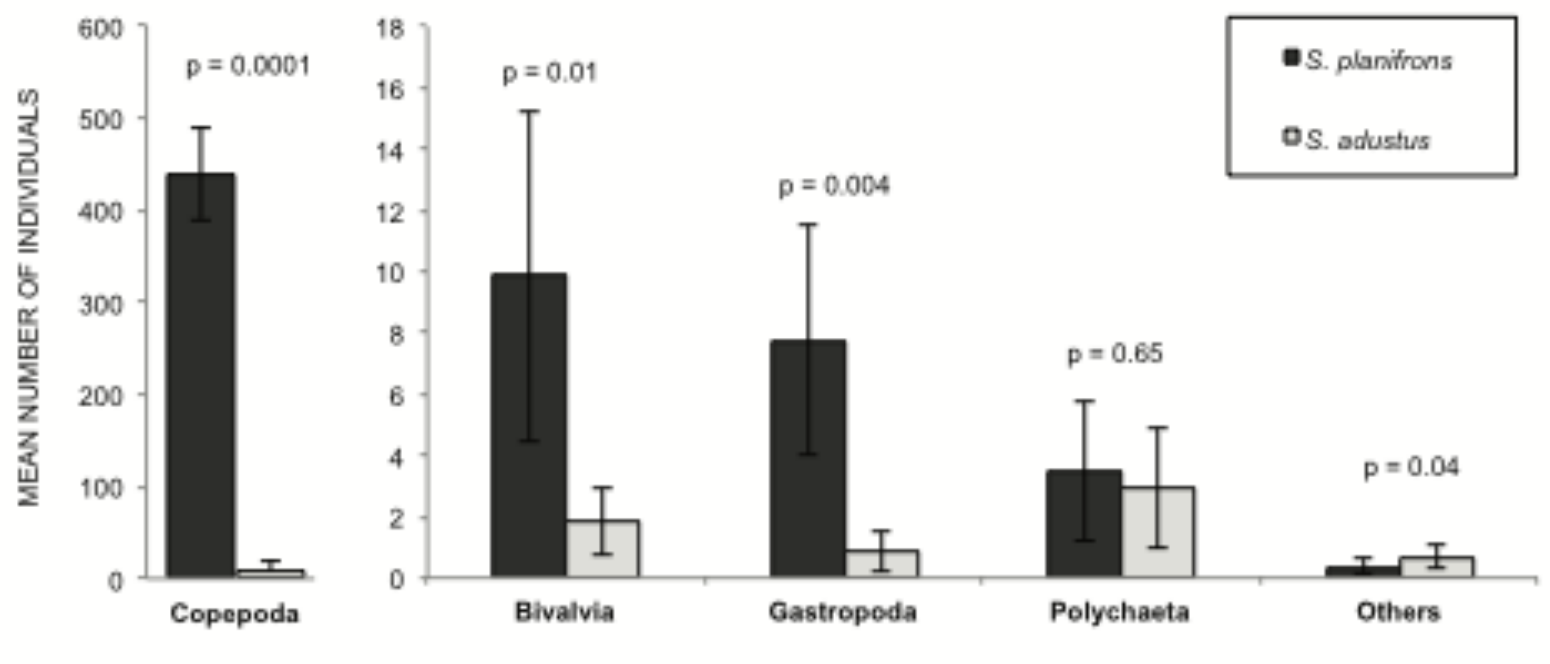

Fig. 3 Mean number of benthic invertebrates $( \pm 95 \% \mathrm{CI})$ recorded in stomach content of Stegastes planifrons (black) and Stegastes adustus (grey), all sites combined. Others = Zoea, Foraminifera, Ostracoda and Penaeidae. Comparisons between S. planifrons and S. adustus were calculated with Student $t$ tests.

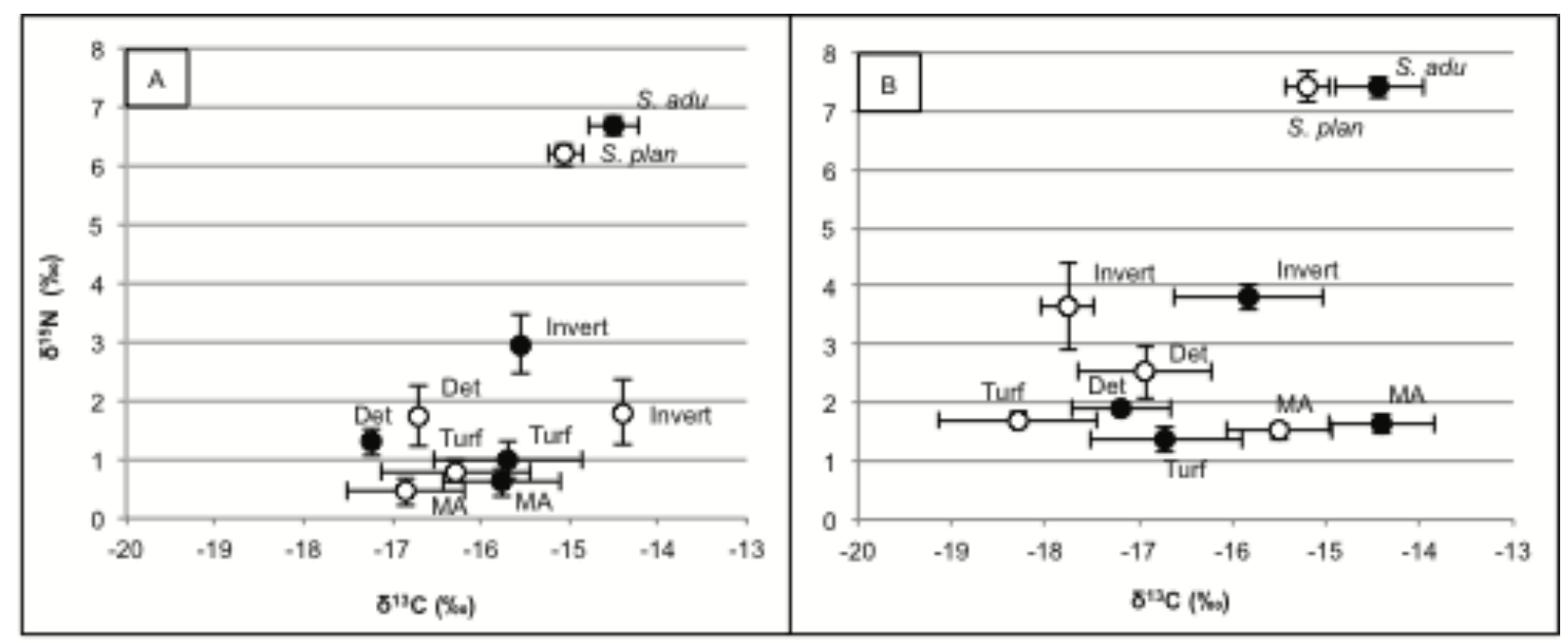

Fig. 4 Mean $( \pm 95 \% \mathrm{CI}) \delta^{13} \mathrm{C}$ and $\delta^{15} \mathrm{~N}$ values of Stegastes planifrons (S.plan, in open symbols), Stegastes adustus (S.adu, in black symbols), and their respective potential food items at Ilets Pigeon (IP) and Passe-à-Colas (PC) Invert: benthic invertebrates; Det: detritus; MA: macroalgae. 


\section{Tables}

\section{Table 1}

Territory size $\left(\mathrm{m}^{2} \pm 95 \% \mathrm{CI}\right)$ of $S$. adustus and S. planifrons at Ilets Pigeon and at Passe-à-Colas. Territory sizes were compared between four situations (two fish species and two sites). p values indicate the results of Tukey's HSD post hoc test. Results in bold show significant differences of territory sizes.

\begin{tabular}{lccc}
\hline Species/sites & Ilets Pigeon & Passe-à-Colas & p values \\
\hline S. planifrons & $1.08 \pm 0.17$ & $1.33 \pm 0.24$ & 0.94 \\
S. adustus & $2.83 \pm 0.57$ & $1.18 \pm 0.26$ & $\mathbf{0 . 0 0 0 1}$ \\
p values & $\mathbf{0 . 0 0 0 1}$ & 0.97 & - \\
\hline
\end{tabular}

\section{Table 2}

Mean number of macroalgae species per territory $( \pm 95 \% \mathrm{CI})$ collected inside $S$. adustus and S. planifrons territories at Ilets Pigeon and Passe-à-Colas. Macroalgae were sorted into three categories (palatable, rare and calcified) and total number of macroalgae species per territory was compared between the four situations (two fish species and two sites). p values indicate the results of Tukey's HSD post hoc test. Results in bold show significant differences.

\begin{tabular}{llccc}
\hline Macroalgae categories & Fish territory & Ilets Pigeon & Passe-à-Colas & p values \\
\hline Palatable macroalgae & S. planifrons & $1.8 \pm 0.4$ & $1.6 \pm 0.5$ & 0.97 \\
& S. adustus & $1.6 \pm 0.5$ & $4.0 \pm 1.1$ & $\mathbf{0 . 0 0 0 6}$ \\
& p value & 0.97 & $\mathbf{0 . 0 0 0 6}$ & - \\
Rare macroalgae & S. planifrons & $0.2 \pm 0.4$ & $1.4 \pm 1.5$ & 0.49 \\
& S. adustus & $0.6 \pm 0.5$ & $2.0 \pm 1.6$ & 0.36 \\
& p value & 0.96 & 0.88 & - \\
Calcified macroalgae & S. planifrons & $0.4 \pm 0.5$ & $1.4 \pm 1.3$ & 0.31 \\
& S. adustus & $1.2 \pm 0.4$ & $4.4 \pm 0.5$ & $\mathbf{0 . 0 0 0 1}$ \\
& p value & 0.49 & $\mathbf{0 . 0 0 0 3}$ & - \\
\hline
\end{tabular}




\section{Table 3}

Mean $( \pm 95 \% \mathrm{CI}) \delta^{13} \mathrm{C}, \delta^{15} \mathrm{~N}$ of Stegastes planifrons, Stegastes adustus and their potential food items at Ilets

Pigeon (A) and at Passe-à-Colas (B). [C]\% and $[\mathrm{N}] \%$ are the elemental concentrations of the sources, used in the mixing models. Comparisons between food source signatures were performed with MANOVAs for each site and for each fish territory. $\mathrm{n}$ is the number of samples.

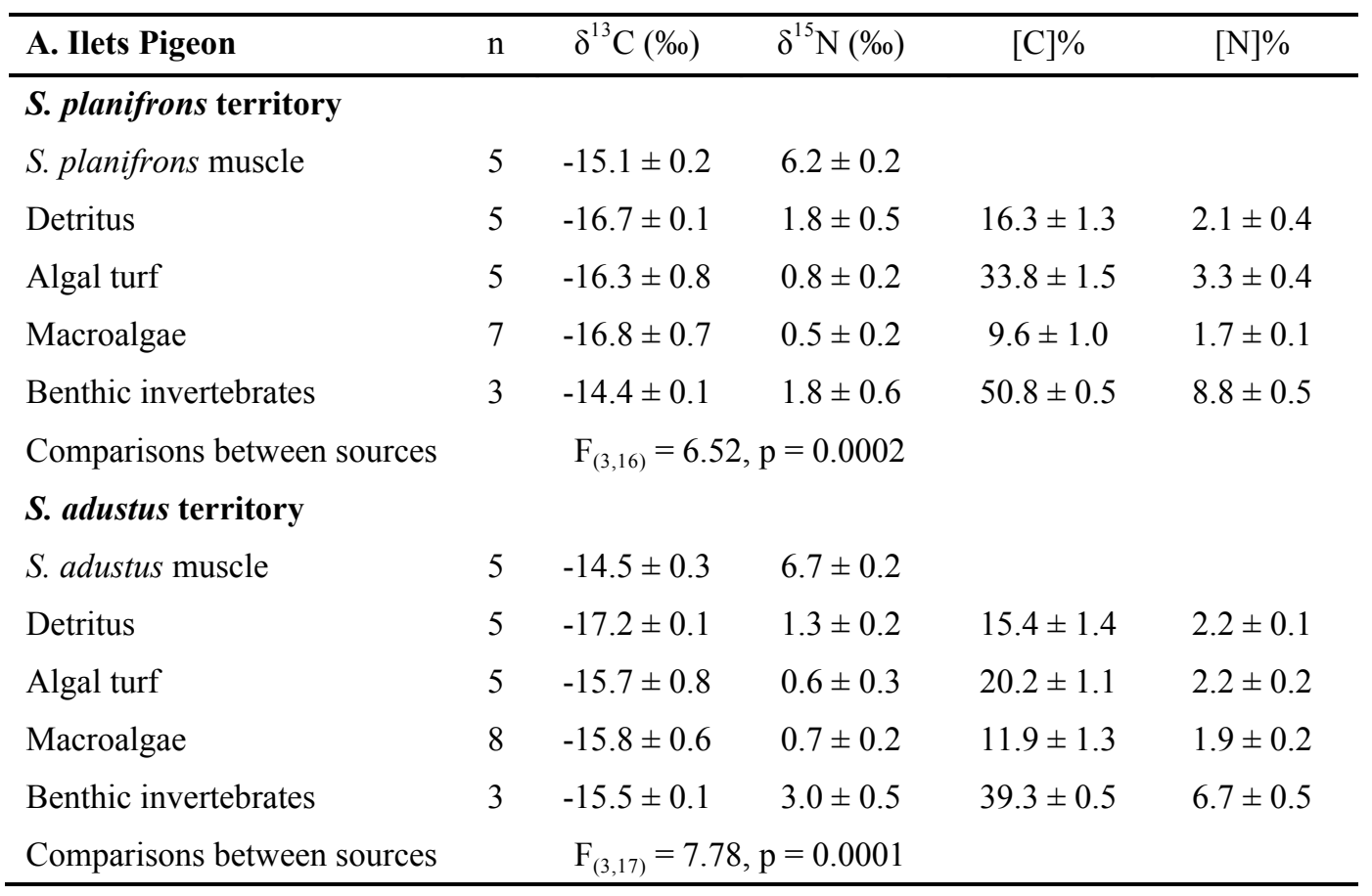

\begin{tabular}{|c|c|c|c|c|c|}
\hline B. Passe-à-Colas & $\mathrm{n}$ & $\delta^{13} \mathrm{C}(\%)$ & $\delta^{15} \mathrm{~N}(\%)$ & {$[\mathrm{C}] \%$} & {$[\mathrm{~N}] \%$} \\
\hline \multicolumn{6}{|l|}{ S. planifrons territory } \\
\hline S. planifrons muscle & 5 & $-15.2 \pm 0.2$ & $7.4 \pm 0.3$ & & \\
\hline Detritus & 5 & $-16.9 \pm 0.7$ & $2.5 \pm 0.4$ & $23.8 \pm 1.2$ & $3.0 \pm 0.7$ \\
\hline Algal turf & 5 & $-18.3 \pm 0.8$ & $1.7 \pm 0.1$ & $33.4 \pm 0.6$ & $2.9 \pm 0.4$ \\
\hline Macroalgae & 7 & $-15.5 \pm 0.5$ & $1.5 \pm 0.2$ & $6.4 \pm 1.7$ & $1.6 \pm 0.2$ \\
\hline Benthic invertebrates & 5 & $-17.8 \pm 0.3$ & $3.6 \pm 0.7$ & $44.6 \pm 0.5$ & $8.3 \pm 0.5$ \\
\hline Comparisons between sources & & \multicolumn{4}{|c|}{$\mathrm{F}_{(3,18)}=13.7, \mathrm{p}=0.0001$} \\
\hline \multicolumn{6}{|l|}{ S. adustus territory } \\
\hline S. adustus muscle & 5 & $-14.4 \pm 0.5$ & $7.4 \pm 0.2$ & & \\
\hline Detritus & 5 & $-17.2 \pm 0.5$ & $1.9 \pm 0.1$ & $17.1 \pm 1.4$ & $2.4 \pm 0.2$ \\
\hline Algal turf & 5 & $-16.7 \pm 0.8$ & $1.4 \pm 0.2$ & $30.3 \pm 2.3$ & $2.7 \pm 0.4$ \\
\hline Macroalgae & 22 & $-14.4 \pm 0.6$ & $1.6 \pm 0.2$ & $5.3 \pm 1.2$ & $1.6 \pm 0.5$ \\
\hline Benthic invertebrates & 5 & $-15.8 \pm 0.8$ & $3.8 \pm 0.2$ & $47.9 \pm 0.5$ & $8.8 \pm 0.5$ \\
\hline Comparisons between sources & & \multicolumn{4}{|c|}{$\mathrm{F}_{(3,33)}=13.5, \mathrm{p}=0.0001$} \\
\hline
\end{tabular}


Table 4

Results of Kruskal-Wallis comparisons testing differences between sites in $\delta^{13} \mathrm{C}$ and $\delta^{15} \mathrm{~N}$ values of Stegastes muscle and values of food resources collected in S. planifrons territories (A) and in S. adustus territories (B). IP: Ilets Pigeon and PC: Passe-à-Colas

\begin{tabular}{lcccc}
\hline A. S. planifrons territories & $\delta$ values & $\mathrm{H}$ & $\mathrm{p}$ & Comparisons \\
\hline Stegastes muscles & $\delta^{13} \mathrm{C}$ & 0.883 & 0.347 & $\mathrm{IP}=\mathrm{PC}$ \\
& $\delta^{15} \mathrm{~N}$ & 6.82 & 0.009 & $\mathrm{IP}<\mathrm{PC}$ \\
Invertebrates & $\delta^{13} \mathrm{C}$ & 5.12 & 0.02 & $\mathrm{IP}>\mathrm{PC}$ \\
& $\delta^{15} \mathrm{~N}$ & 5.0 & 0.03 & $\mathrm{IP}<\mathrm{PC}$ \\
Algal Turf & $\delta^{13} \mathrm{C}$ & 2.69 & 0.10 & $\mathrm{IP}=\mathrm{PC}$ \\
& $\delta^{15} \mathrm{~N}$ & 5.0 & 0.03 & $\mathrm{IP}<\mathrm{PC}$ \\
Macroalgae & $\delta^{13} \mathrm{C}$ & 5.0 & 0.03 & $\mathrm{IP}<\mathrm{PC}$ \\
& $\delta^{15} \mathrm{~N}$ & 9.8 & 0.002 & $\mathrm{IP}<\mathrm{PC}$ \\
Detritus & $\delta^{13} \mathrm{C}$ & 0.27 & 0.602 & $\mathrm{IP}=\mathrm{PC}$ \\
& $\delta^{15} \mathrm{~N}$ & 3.17 & 0.05 & $\mathrm{IP}<\mathrm{PC}$ \\
\hline \multirow{3}{*}{ B. S. adustus territories } & & & & \\
\hline Stegastes muscles & $\delta$ values & $\mathrm{H}$ & $\mathrm{p}$ & $\mathrm{Comparisons}$ \\
\hline \multirow{2}{*}{ Invertebrates } & $\delta^{13} \mathrm{C}$ & 0.01 & 0.917 & $\mathrm{IP}=\mathrm{PC}$ \\
& $\delta^{15} \mathrm{~N}$ & 6.82 & 0.009 & $\mathrm{IP}<\mathrm{PC}$ \\
Algal Turf & $\delta^{13} \mathrm{C}$ & 0.20 & 0.651 & $\mathrm{IP}=\mathrm{PC}$ \\
& $\delta^{15} \mathrm{~N}$ & 0.2 & 0.655 & $\mathrm{IP}=\mathrm{PC}$ \\
& $\delta^{13} \mathrm{C}$ & 3.94 & 0.05 & $\mathrm{IP}>\mathrm{PC}$ \\
& $\delta^{15} \mathrm{~N}$ & 3.94 & 0.05 & $\mathrm{IP}<\mathrm{PC}$ \\
& $\delta^{13} \mathrm{C}$ & 2.11 & 0.146 & $\mathrm{IP}<\mathrm{PC}$ \\
& $\delta^{15} \mathrm{~N}$ & 10.5 & 0.001 & $\mathrm{IP}<\mathrm{PC}$ \\
& $\delta^{15} \mathrm{C}$ & 0.28 & 0.599 & $\mathrm{IP}=\mathrm{PC}$ \\
& 6.86 & 0.009 & $\mathrm{IP}<\mathrm{PC}$ \\
\hline
\end{tabular}


Table 5

Results of Kruskal-Wallis comparisons testing differences in $\delta^{13} \mathrm{C}$ and $\delta^{15} \mathrm{~N}$ values of Stegastes muscle and values of food resources between fish territory at Ilets Pigeon (A) and at Passe-à-Colas (B). S. plan: Stegastes planifrons territories and S. adu: Stegastes adustus territories

\begin{tabular}{lcccc}
\hline A. Ilets Pigeon & Signatures & $\mathrm{H}$ & $p$ & Comparisons \\
\hline Stegastes muscles & $\delta^{13} \mathrm{C}$ & 4.81 & 0.02 & S. plan $<$ S. $a d u$ \\
& $\delta^{15} \mathrm{~N}$ & 5.77 & 0.02 & S. plan $<$ S. $a d u$ \\
Invertebrates & $\delta^{13} \mathrm{C}$ & 3.86 & 0.04 & S. plan $>$ S. $a d u$ \\
& $\delta^{15} \mathrm{~N}$ & 1.19 & 0.28 & S. plan $=$ S. $a d u$ \\
Algal Turf & $\delta^{13} \mathrm{C}$ & 1.84 & 0.17 & S. plan $=$ S. $a d u$ \\
& $\delta^{15} \mathrm{~N}$ & 0.09 & 0.75 & S. plan $=$ S. $a d u$ \\
Macroalgae & $\delta^{13} \mathrm{C}$ & 0.48 & 0.48 & S. plan $=$ S. $a d u$ \\
& $\delta^{15} \mathrm{~N}$ & 0.01 & 0.91 & S.plan $=S . a d u$ \\
Detritus & $\delta^{13} \mathrm{C}$ & 6.90 & 0.008 & S. plan $>$ S. $a d u$ \\
& $\delta^{15} \mathrm{~N}$ & 1.35 & 0.25 & S. plan $=S . a d u$ \\
\hline
\end{tabular}

\begin{tabular}{lcccc}
\hline B. Passe-à-Colas & Signatures & $\mathrm{H}$ & $p$ & Comparisons \\
\hline Stegastes muscles & $\delta^{13} \mathrm{C}$ & 6.82 & 0.009 & S. plan $<$ S. $a d u$ \\
& $\delta^{15} \mathrm{~N}$ & 0.02 & 0.91 & S. plan $=$ S. $a d u$ \\
Invertebrates & $\delta^{13} \mathrm{C}$ & 6.99 & 0.008 & S. plan $<$ S. $a d u$ \\
& $\delta^{15} \mathrm{~N}$ & 0.09 & 0.75 & S. plan $=$ S. $a d u$ \\
Algal Turf & $\delta^{13} \mathrm{C}$ & 2.69 & 0.10 & S. plan $=$ S. $a d u$ \\
& $\delta^{15} \mathrm{~N}$ & 2.69 & 0.10 & S. plan $=$ S. $a d u$ \\
Macroalgae & $\delta^{13} \mathrm{C}$ & 0.37 & 0.54 & S. plan $=$ S. $a d u$ \\
& $\delta^{15} \mathrm{~N}$ & 1.37 & 0.24 & S. plan $=$ S. $a d u$ \\
Detritus & $\delta^{13} \mathrm{C}$ & 0.884 & 0.347 & S. plan $=$ S. $a d u$ \\
& $\delta^{15} \mathrm{~N}$ & 5.806 & 0.010 & S. plan $>$ S. $a d u$ \\
\hline
\end{tabular}




\section{Table 6}

Mean biomass contribution (Bayesian credibility interval 95\%) of each food source to Stegastes planifrons and Stegastes adustus diet estimated with concentration dependent mixing model, Stable Isotope Analysis in R (SIAR). Results are given for the two sites: Ilets Pigeon (IP) and Passe-à-Colas (PC)

\begin{tabular}{lcccc}
\hline $\begin{array}{l}\text { Fish species } \\
\text { Studied sites }\end{array}$ & IP & PC & IP & PC adustus \\
\hline Diet contribution (\%) & & & & \\
Algal turf & $26.7(1.7-48.7)$ & $21.0(0.2-41.9)$ & $23.9(1.2-43.5)$ & $25.3(1.1-46.8)$ \\
Macroalgae & $33.2(4.0-57.9)$ & $37.2(5.7-67.4)$ & $29(2.1-51.2)$ & $32.9(2.1-59.5)$ \\
Detritus & $31.9(3.7-55.4)$ & $30.8(3.8-54.1)$ & $31.3(5.4-54.1)$ & $29.1(2.1-51.5)$ \\
Benthic invertebrates & $8.2(0.0-19.6)$ & $11.0(0.0-25.6)$ & $15.8(3.2-31.1)$ & $12.7(1.5-27.4)$ \\
\hline
\end{tabular}


Table 7

Mean concentrations of biochemical components $\left(\mathrm{mg} \mathrm{g}^{-1} \pm 95 \% \mathrm{CI}\right)$ of the four food sources: detritus (D), algal turf (T), Invertebrate (I) and "palatable" macroalgae (M), collected inside Stegastes territories at Ilets Pigeon (A) and Passe-à-Colas (B). Comparisons of concentrations between food categories were performed with one-way ANOVAs using food category as factor. Multiple comparisons between food categories were done with Tukey HSD tests. S. Carbohyd: soluble carbohydrates; I. Carbohyd: insoluble carbohydrates

\begin{tabular}{lcccc}
\hline A. Ilets Pigeon & Proteins & Lipids & S. Carbohyd. & I. Carbohyd. \\
\hline Detritus & $7.9 \pm 1.5$ & $7.4 \pm 1.3$ & $12.4 \pm 3.2$ & $17.6 \pm 3.0$ \\
Algal turf & $9.9 \pm 2.2$ & $7.9 \pm 1.5$ & $21.6 \pm 6.5$ & $63.7 \pm 9.8$ \\
Macroalgae & $30.5 \pm 8.6$ & $29.6 \pm 7.0$ & $61.4 \pm 24.8$ & $75.7 \pm 11.1$ \\
Invertebrates & $8.2 \pm 1.7$ & $7.0 \pm 0.7$ & $10.5 \pm 1.7$ & $5.1 \pm 1.7$ \\
Results of ANOVAs & $\mathrm{F}_{(3,42)}=12.6$ & $\mathrm{~F}_{(3,39)}=28.2$ & $\mathrm{~F}_{(3,42)}=7.34$ & $\mathrm{~F}_{(3,40)}=82.2$ \\
$p$ values & $p=0.0001$ & $p=0.0001$ & $p=0.0005$ & $p=0.0001$ \\
Multiple comparisons & $\mathrm{T}=\mathrm{D}=\mathrm{I}<\mathrm{M}$ & $\mathrm{T}=\mathrm{D}=\mathrm{I}<\mathrm{M}$ & $\mathrm{T}=\mathrm{D}=\mathrm{I}<\mathrm{M}$ & $\mathrm{D}=\mathrm{I}<\mathrm{T}<\mathrm{M}$ \\
\hline
\end{tabular}

\begin{tabular}{lcccc}
\hline B. Passe-à-Colas & Proteins & Lipids & S. Carbohyd. & I. Carbohyd. \\
\hline Detritus & $8.9 \pm 1.3$ & $5.3 \pm 0.6$ & $8.8 \pm 1.5$ & $19.8 \pm 2.3$ \\
Algal turf & $1.5 \pm 1.0$ & $4.8 \pm 0.9$ & $13.5 \pm 5.6$ & $38.3 \pm 5.4$ \\
Macroalgae & $32.2 \pm 8.5$ & $31.5 \pm 5.9$ & $57.6 \pm 14.2$ & $85.6 \pm 11.0$ \\
Invertebrates & $8.2 \pm 1.7$ & $7.0 \pm 0.7$ & $10.5 \pm 1.7$ & $5.1 \pm 1.7$ \\
Results of ANOVAs & $\mathrm{F}_{(3,79)}=11.1$ & $\mathrm{~F}_{(3,79)}=22.5$ & $\mathrm{~F}_{(3,79)}=20.4$ & $\mathrm{~F}_{(3,76)}=49.5$ \\
$p$ values & $p=0.0001$ & $p=0.0001$ & $p=0.0001$ & $p=0.0001$ \\
Multiple comparisons & $\mathrm{T}=\mathrm{D}=\mathrm{I}<\mathrm{M}$ & $\mathrm{T}=\mathrm{D}=\mathrm{I}<\mathrm{M}$ & $\mathrm{T}=\mathrm{D}=\mathrm{I}<\mathrm{M}$ & $\mathrm{D}=\mathrm{I}<\mathrm{T}<\mathrm{M}$ \\
\hline
\end{tabular}

